\title{
Holmium: YAG Versus Cold Knife Internal Urethrotomy in the Management of Short Urethral Strictures: A Randomized Controlled Trial
}

\author{
Mohamed A. Gamal' ${ }^{1}$ Ahmed Higazy ${ }^{1 * \mathbb{D}}$, Samuel F. Ebskharoun², Ahmed Radwan ${ }^{1}$ \\ ${ }^{1}$ Ain Shams University Hospital, Cairo, Egypt \\ ${ }^{2}$ Maadi Military Hospital, Cairo, Egypt
}

*Correspondence to

Ahmed Higazy,

Ain Shams University Hospital,

Cairo, Egypt.

Tel: +20/ 01002609801,

E-mail: Ahmedmaherhigazy@

gmail.com

Received: December 8, 2020 Accepted: April 5, 2021

Published online July 18, 2021

\begin{abstract}
Introduction: our study aimed to assess the safety and efficacy of Holmium: YAG laser internal urethrotomy compared to the cold knife internal urethrotomy.

Methods: Eighty adult male patients presented with a urethral stricture less than $1.5 \mathrm{~cm}$ were included in our study; they were randomly allocated into 2 groups representing Holmium and cold knife internal urethrotomy. A careful evaluation with ascending cystourethrogram and uroflowmetry were done on all patients, and they were followed up for 1 year with uroflowmetry.

Results: Each group included 40 patients sharing the same demographic data. The most common cause of a urethral stricture in both groups was iatrogenic injury. The mean operative time of the cold knife urethrotomy procedure was $10.98 \pm 2.40$ minutes compared to $15.43 \pm 2.48$ minutes in the holmium laser urethrotomy group with a highly significant difference. The results showed success rates of $90 \%$ and $80 \%$ for the holmium laser and cold knife internal urethrotomy groups respectively. The perioperative complication according to the Clavien-Dindo classification, showed no statistically significant difference in grade 1 and 2 complications. A recurrence rate with the need for redo surgery representing grade $3 \mathrm{~B}$ complication was seen in 4 cases in the Holmium group compared to 8 cases in the cold knife group with a statistically significant difference.

Conclusion: Both Holmium Laser and cold knife internal urethrotomy are an effective surgical option for the treatment of a urethral stricture less than $1.5 \mathrm{~cm}$ with a promising outcome after 1-year follow-up with a better success rate using the Holmium laser.

Keywords: Holmium laser, Urethral stricture, Outflow obstruction, Internal urethrotomy, Uroflowmetry
\end{abstract}

\section{Introduction}

The urethral stricture is common urological morbidity affecting the voiding function and quality of life, where the severity of the symptomatology depends on the degree and length of the urethral stricture. ${ }^{1}$ One of the most common causes for the urethral stricture was urethritis, especially following chronic infection over years rather than a single infection. However, with more endourological surgeries being done, iatrogenic urethral injury from instrumentation, urethral catheterization or thermal energy following an endourological procedure became the most common causes followed by idiopathic causes. Other traumatic causes induced urethral injury include pelvic fracture, straddle trauma to the perinium, previous urethral surgeries like hypospadias repair which may impact the overall prognosis..$^{2-5}$

The management of the urethral stricture is planned according to the site and length of the stricture. The 2 main surgical interventions are endoscopic visual internal urethrotomy and open urethral reconstruction. ${ }^{4}$ Cold knife endoscopic visual internal urethrotomy was first used by Sachse in 1971, and it is the most commonly used surgical treatment for a urethral stricture less than $2 \mathrm{~cm}$ in the posterior urethra. It has gained popularity for being safe, effective with an excellent outcome. VIU is a simple procedure with a short learning curve and associated with a low complication rate and a short hospital stay. ${ }^{5}$

Laser urethrotomy was first introduced in 1979. However, it failed to gain enough attention from surgeons at that time. ${ }^{7,8}$ Later, the holmium: YAG (Ho:YAG) laser started to gain attention in the management of a urethral stricture less than $1.5 \mathrm{~cm}$ as an effective alternative to the gold standard cold knife internal urethrotomy as it has shown a comparable outcome in both safety and efficacy. ${ }^{8,9}$

The Ho:YAG laser provides ablation energy with adequate hemostasis that provides a clear field of vision during the procedure. In addition, it causes minimal 
damage to the surrounding structure due to the minimal penetration depth of $0.4 \mathrm{~mm} .^{5,10}$ We aimed, through our study, to evaluate the efficacy and safety of the holmium laser application in the management of a urethral stricture in comparison to the standard cold knife internal urethrotomy.

\section{Materials and Methods}

Eight patients were included in our study, complaining of obstructive urinary symptoms secondary to a urethral stricture between March 2017 and December 2019. The patients were randomly allocated in our study into 2 equal groups with a ratio of 1:1 using a computer-based system after obtaining informed consent under the supervision of the local ethical committee. Group A represented the holmium laser internal urethrotomy while group B represented the Sachse cold knife internal urethrotomy. All adult male patients aged above 18 years with a urethral stricture measuring less than $1.5 \mathrm{~cm}$ were included in our study. A urethrogram study and uroflowmetry were done on all patients before surgery except for those with a suprapubic catheter. Pelviabdominal ultrasound was done to evaluate the presence of benign prostatic hyperplasia to exclude patients with enlarged prostate from our study. Those patients who had previously undergone surgical repair of the urethral stricture were excluded from our study. A careful evaluation was done to exclude patients with complete urethral lumen obstruction, multiple urethral strictures or balanitis xerotica obliterans. Any associated urinary tract infection (UTI) was treated properly before surgery.

All procedures were done by a single expert surgeon. The patients were placed in the lithotomy position under general or regional anesthesia. A 21 Fr cystoscope was used to evaluate the urethra, and a guidewire was passed to the urinary bladder. In the holmium laser group, a 365-micron laser fiber (end firing laser fiber) was used to deliver pulse energy of 1 joule with a frequency of $15 \mathrm{~Hz}$ and power of 15 watts generated from a Holmium laser device (Cyber Ho 35-watt, Quanta device, Milano, Italy).

The laser fiber was aimed at the 12 o'clock position of the urethral stricture using the end firing property of the laser fiber to incise the fibrotic tissue until an adequate lumen is opened with tissue ablation. In the other group, a rectangular cold knife was used in the endoscopic internal urethrotomy at the same site to incise the urethral stricture; this was followed by meatal dilatation of the urethra that was done only once in the intraoperative setting before urinary catheter insertion. A single dose of prophylactic antibiotic was given to all patients. A urethral catheter was kept in place for 7 days, and then it was removed in the outpatient clinic.

Our primary outcome measure was the improvement in the maximum flow rate (Qmax) in both techniques compared to the baseline and the other group at the same time interval, while our secondary outcome measures included operative time, perioperative complication, recurrence of symptoms, and the need for redo surgery which was determined by patient complaints and a urethrogram to diagnose the recurrence of a urethral stricture.

Operative time was recorded from diagnostic urethroscopy until urethral catheter insertion. Perioperative complications like extravasation, bleeding, urinary tract infection, or erectile dysfunction were recorded. The patients were assessed at the interval of 3 months and 12 months after the procedure with uroflow to evaluate the voiding pattern. Cases with the recurrence of stricture that needed redo surgery were documented in both procedures. The success of the procedure was considered with a Qmax result of more than $15 \mathrm{~m} / \mathrm{s}$. urethrogram done was done for patients with symptoms recurrence or for those whom Qmax dropped below $15 \mathrm{~m} / \mathrm{s}$. No passive dilatation was done to our patients postoperatively.

\section{Statistical Analysis}

Data were analyzed using IBM SPSS version 23, and they were expressed as mean \pm SD for quantitative parametric measures and both number and percentage for categorical data. A chi-square test was used to compare the qualitative data between groups. The comparison between two independent groups with quantitative data and parametric distribution was done by using an independent-samples $t$ test. The comparison between two paired groups with quantitative data and parametric distribution was done by using a paired-samples $t$ test. A $P$ value $<0.05$ was considered statistically significant and less than 0.01 was considered highly significant.

\section{Results}

Eighty patients were enrolled in our study as shown in Figure 1. There was no difference in the demographic data between both groups as shown in Table 1 . The iatrogenic urethral stricture was the most common in both arms of our study with no statistical difference regarding etiology between both arms as shown in Table 1. A shorter operative time was recorded in the cold knife urethrotomy group with a mean operative time of 10.98 \pm 2.4 minutes compared to $15.43 \pm 2.48$ minutes in the Holmium laser internal urethrotomy group with a highly significant difference $(P$ value $<0.001)$.

The Qmax showed a statistically significant improvement in both groups in the 12-months followup period compared to the preoperative data in both groups $(P$ value $<0.001)$ with no statistically significant difference between the groups in any time interval during our follow-up as shown in Table 2. The overall change in the Qmax in both groups is shown in Figure 2.

Regarding the peri-operative complication, there was no 


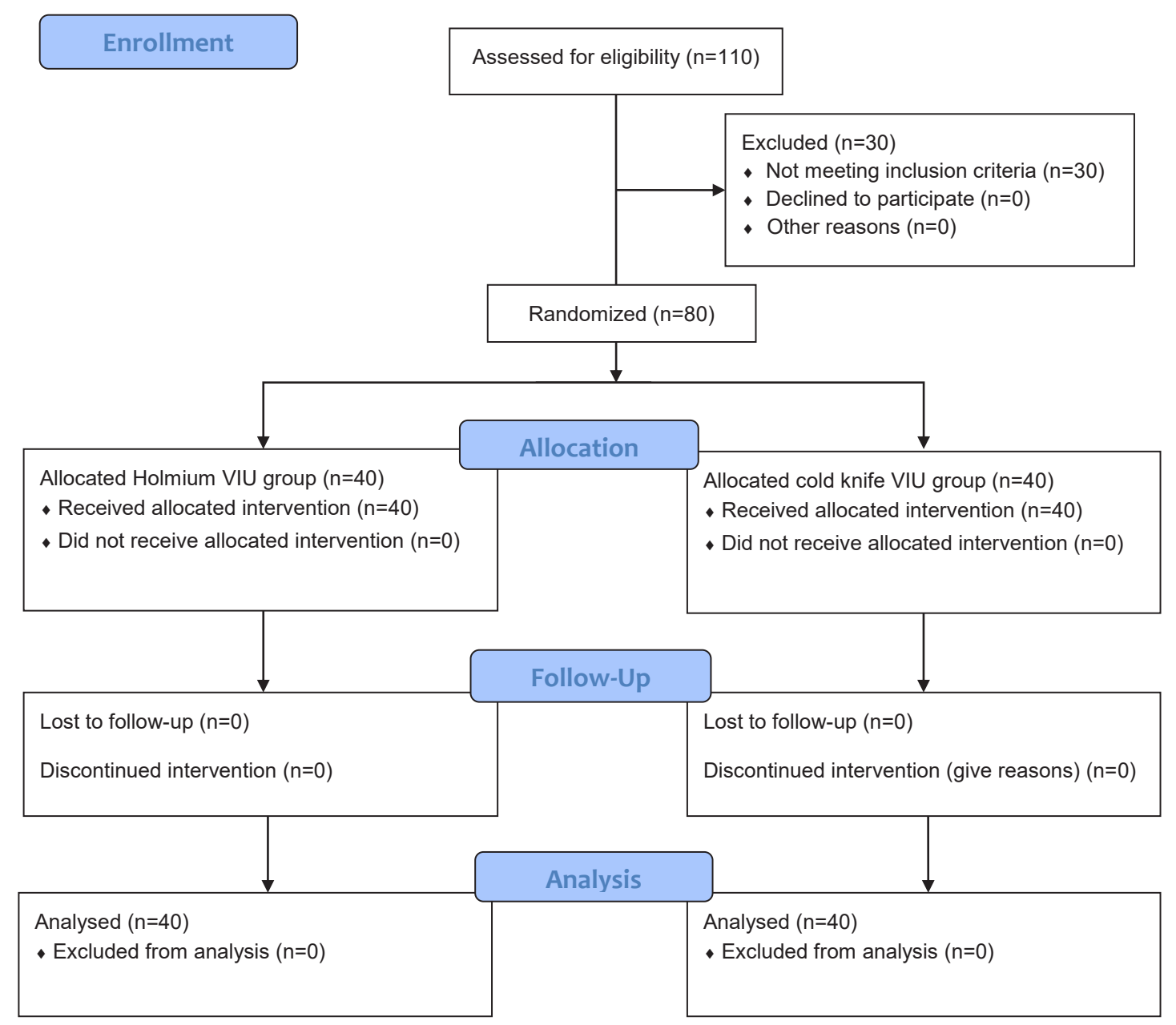

Figure 1. consort flow chart

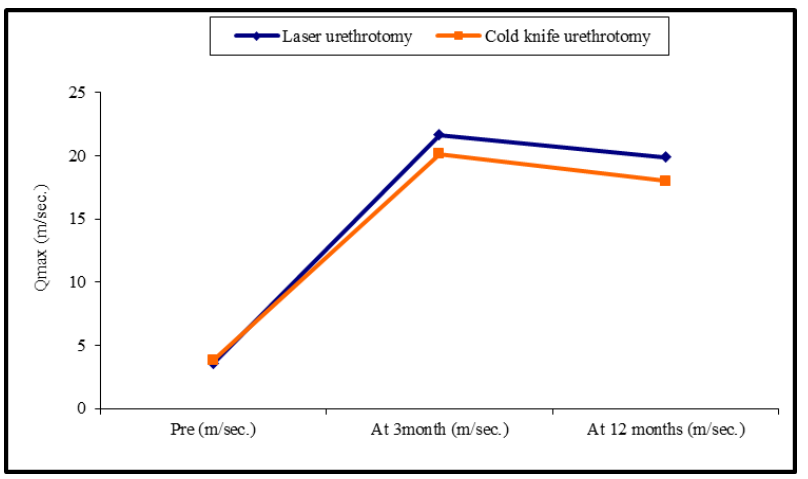

Figure 2: Uroflow curve

statistically significant difference between both groups as shown in Table 3. Regarding the recurrence rate and those patients who needed a redo surgery in our study, it was seen in 4 cases of group A compared to 8 cases in group $B$ with no statistically significant difference between them $(P$ value $=0.044)$. All patients with recurrence of stricture were revaluated using a new urethrogram and they were scheduled for a redo-surgery.

\section{Discussion}

The urethral stricture is a common challenging urological problem dating from ancient times, causing obstructed voiding symptoms and affecting the quality of life (1). There are numerous causes for the urethral stricture, including urinary tract infection, straddle trauma, pelvic fracture, previous hypospadias repair (2).

Cold knife internal urethrotomy was first described by Sachse in 1971, and it is considered the gold standard procedure in the surgical management of a urethral stricture less than $2 \mathrm{~cm}$ in the posterior urethra (5). Variable results regarding the success rate have been published by many studies. However, the success rate reported by most of them was over $70 \%(11,12)$.

This intervention is minimally invasive with less morbidity and hospital stay compared to open surgery. Additionally, it is safe with low rate of peri-operative complication, with a short learning curve and easy to be repeated. However, it is associated with a considerable recurrence rate of the urethral stricture. This high rate of recurrence cannot probably be explained, but it may be 
Table 1. Age, Etiology, and Operative Time

\begin{tabular}{|c|c|c|c|c|}
\hline & & $\begin{array}{c}\text { Laser Urethrotomy } \\
\text { (Group A) }\end{array}$ & $\begin{array}{c}\text { Cold Knife Urethrotomy } \\
\text { (Group B) }\end{array}$ & \multirow[t]{2}{*}{$P$ Value } \\
\hline & & $n=40$ & $n=40$ & \\
\hline Age & Mean \pm SD & $46.68 \pm 13.19$ & $47.58 \pm 13.26$ & 0.762 \\
\hline \multirow{4}{*}{ Etiology } & Post traumatic (falling astride) & $7(17.5 \%)$ & $7(17.5 \%)$ & \multirow{4}{*}{0.739} \\
\hline & Urinary tract infection & $11(27.5 \%)$ & $11(27.5 \%)$ & \\
\hline & latrogenic (catheter induced) & $19(47.5 \%)$ & $16(40.0 \%)$ & \\
\hline & Idiopathic & $3(7.5 \%)$ & $6(15.0 \%)$ & \\
\hline \multirow{3}{*}{ Site of stricture } & Bulbar & 30 & 29 & \multirow{3}{*}{0.423} \\
\hline & Penile & 7 & 6 & \\
\hline & Posterior urethra & 3 & 5 & \\
\hline Operation time (min) & Mean \pm SD & $15.43 \pm 2.48$ & $10.98 \pm 2.40$ & $<0.001$ \\
\hline
\end{tabular}

Table 2. Uroflowmetry

\begin{tabular}{lccc}
\hline Time of Qmax Assessment $(\mathbf{m L} / \mathbf{s})$ & Preoperative & 3 Months & 12 Months \\
\hline Laser urethrotomy (group A) & $3.58 \pm 0.71$ & $20.65 \pm 1.82$ & $19.88 \pm 3.71$ \\
Cold knife urethrotomy (group B) & $3.85 \pm 0.98$ & $19.15 \pm 1.39$ & $17.03 \pm 4.42$ \\
$P$ value & 0.845 & 0.203 & 0.559 \\
\hline
\end{tabular}

Table 3. Perioperative Complication

\begin{tabular}{|c|c|c|c|c|c|}
\hline Clavien-Dindo Classification & & $\begin{array}{l}\text { Laser Urethrotomy } \\
\text { (Group A) }\end{array}$ & $\begin{array}{l}\text { Cold Knife Urethrotomy } \\
\text { (Group B) }\end{array}$ & $P$ Value & $\begin{array}{c}\text { Study } \\
\text { Population } \\
(\mathrm{N}=\mathbf{8 0})\end{array}$ \\
\hline \multirow{2}{*}{$\begin{array}{l}\text { Grade } 1 \text { (deviation from the } \\
\text { normal course without the need for } \\
\text { pharmacological treatment or surgical } \\
\text { interventions) }\end{array}$} & Bleeding per urethra & $1(2.5 \%)$ & $2(2.5 \%)$ & 0.654 & \multirow[b]{2}{*}{$7(8.75 \%)$} \\
\hline & Penile extravasation & $1(2.5 \%)$ & $3(7.5 \%)$ & 0.455 & \\
\hline Grade 2 (pharmacological management) & UTI & $3(7.5 \%)$ & $1(2.5 \%)$ & 0.325 & $4(5 \%)$ \\
\hline $\begin{array}{l}\text { Grade } 3 \text { - B (Procedure under regional or } \\
\text { general anesthesia) }\end{array}$ & $\begin{array}{l}\text { Urethral stricture } \\
\text { recurrence }\end{array}$ & $4(10 \%)$ & $8(20 \%)$ & 0.044 & $12(15 \%)$ \\
\hline Overall complication & & $9(22.5 \%)$ & $14(27.5 \%)$ & 0.721 & $23(28.8 \%)$ \\
\hline
\end{tabular}

UTI, urinary tract infection; SUI, Stress urinary incontinence.

related to the urethral scar tissue and excess fibrosis with lateral contracture (13-15).

Laser urethrotomy was first introduced in 1979, and it has been shown to be effective in a short segment stricture less than $1.5 \mathrm{~cm}$ with a comparable outcome to the gold standard cold knife optical urethrotomy $(8,16,17)$. The Ho:YAG laser has a penetration depth of $0.4 \mathrm{~mm}$ with adequate hemostasis, giving the advantage of ablation with less bleeding that allows a more clear field with minimal peripheral damage to the surrounding tissue (10). It remains controversial among different studies regarding the superiority of one technique over the other.

The etiology of the urethral stricture in our study was mainly an iatrogenic cause representing $43.75 \%$ of cases followed by the UTI induced urethral stricture with an incidence of $27.5 \%$, then traumatic and idiopathic causes. Their results were consistent with the previous reports where false catheterization or endoscopic instrumentation represented the most common causes in adult patients. $(4,7,18)$

Our study showed a shorter mean operative time of $10.98 \pm 2.40$ minutes in the cold knife group compared to a mean time of $15.43 \pm 2.48$ minutes in the laser group with a highly significant difference. However, the clinical significance was hard to achieve in 5 minutes. These results were comparable to a study that was done by Atak et al showing cold knife mean operative time of $7.44 \mathrm{~min}$ (range 5-10 $\mathrm{min}$ ) and Holmium internal urethrotomy operative time of 8.4-16.4 minutes. Also, Singh et al reported a mean operative time in cold knife urethrotomy to be 7.44 minutes compared to 19.8 minutes in laser urethrotomy (7); this could be related to some technical demanding time of the laser fiber to ablate fibrous tissues, not just mechanical incision (19). 
The success rate in our study was estimated by a Qmax of more than $15 \mathrm{~mL} / \mathrm{s}$ in the uroflowmetry 12 months after the surgery in both groups. The mean Qmax in group A was $20.65 \pm 1.82 \mathrm{~mL} / \mathrm{s}$ compared to $19.15 \pm$ $1.39 \mathrm{~mL} / \mathrm{s}$ in group B with a highly significant difference compared to the preoperative values of both techniques with no statistical or clinical difference between both groups at the same follow-up period. The follow-up of our patients after 1 year revealed a decrease in the Qmax in both groups, where the mean Qmax in group A was 19.88 $\pm 3.71 \mathrm{~mL} / \mathrm{s}$ compared to $17.03 \pm 4.42 \mathrm{~mL} / \mathrm{s}$ in group $\mathrm{B}$.

The success rate in our study was $90 \%$ in group A compared to $80 \%$ in group B with a statistically significant difference. Previous studies that were done by Mazo et al, Dogra et al. and Lagerveld et al. reported the superiority of the laser over cold knife urethrotomy in terms of uroflow improvement $(7,8,16,17)$. Laser urethrotomy in our study showed a better visualization duration laser ablation because of the hemostatic effect that provided an accurate site of ablation with a meticulous depth of ablation and trimming of the edges with the vaporization of the scar tissue.

Regarding the recurrence of urethral stricture and the need for a redo surgery, it was seen in 12 cases of our study population representing $15 \%$ of the whole population, 4 of them were in the laser group compared to 8 cases in the cold knife group. The success rate was enhanced by the proper treatment of the urinary tract as it could increase the success rate from $28 \%$ to $72 \%$. (7)

A randomized clinical study reported by Atak et al. showed success rates of $81 \%$ and $53 \%$ at 12 months for holmium and cold knife urethrotomy respectively (19). Yenice et al. reported a mean success rate of $79.3 \%$ and $67.6 \%$ for cold knife and Holmium urethrotomy respectively (18). Dutkiewicz and Wroblewski indicated that no superiority was confirmed for the holmium laser over the classical cold knife internal urethrotomy at a 1-year follow-up (11).

Karkan et al reported a $73.2 \%$ success rate with Holmium urethrotomy in their clinical experience with 138 patients (20). Evaluation of previous studies is shown in Table 4.

The reported incidence of perioperative complications varies greatly in different studies. Regarding our study, we documented our complications according to the ClavienDindo classification. As shown in Table 3, the overall

Table 4. previous studies evaluated Holmium and cold knife VIU

\begin{tabular}{|c|c|c|c|c|c|c|c|c|}
\hline Study & $\begin{array}{l}\text { Type of } \\
\text { studies }\end{array}$ & $\begin{array}{l}\text { Number } \\
\text { of } \\
\text { patients }\end{array}$ & $\begin{array}{l}\text { Arms of the } \\
\text { study }\end{array}$ & $\begin{array}{l}\text { Primary } \\
\text { end point }\end{array}$ & $\begin{array}{c}\text { Secondary end } \\
\text { point }\end{array}$ & Success rate & complication & limitation \\
\hline $\begin{array}{l}\text { Dogra et al. } \\
2002\end{array}$ & $\begin{array}{l}\text { Retrospective } \\
\text { cohort }\end{array}$ & 61 & $\begin{array}{c}\text { Singles } \\
\text { (Holmium } \\
\text { VIU) }\end{array}$ & $\begin{array}{l}\text { Improved } \\
\text { Qmax at } 3 \\
\text { months > } \\
15 \mathrm{ml} / \mathrm{sec} \text {. }\end{array}$ & $\begin{array}{l}\text { Operative time } \\
\text { Durable success } \\
\text { rate till } 30 \\
\text { months }\end{array}$ & $96 \%$ & $\begin{array}{c}\text { Recurrence of } \\
\text { stricture in } 2 \\
\text { cases }\end{array}$ & $\begin{array}{c}\text {-Lack of } \\
\text { comparative } \\
\text { arm } \\
\text {-Retrospective } \\
\text { nature of the } \\
\text { study }\end{array}$ \\
\hline $\begin{array}{l}\text { Singh et al. } \\
2014\end{array}$ & $\begin{array}{c}\text { Randomized } \\
\text { controlled } \\
\text { trial }\end{array}$ & 90 & $\begin{array}{l}\text { Cold knife } \\
\text { versus VIU }\end{array}$ & $\begin{array}{l}\text { Improved } \\
\text { Qmax at } 3 \\
\text { months > } \\
15 \mathrm{ml} / \mathrm{sec}\end{array}$ & $\begin{array}{l}\text { Operative time } \\
\text { Postoperative } \\
\text { complication }\end{array}$ & $100 \%$ & $\begin{array}{l}\text { Overall, } 13.3 \% \\
\text { including } \\
\text { urethral bleeding, } \\
\text { postoperative } \\
\text { pain, UTI, and } \\
\text { recurrence in } 6 \\
\text { cases }\end{array}$ & $\begin{array}{l}\text {-Short duration } \\
\text { of follow up. }\end{array}$ \\
\hline $\begin{array}{l}\text { Atak et al. } \\
2011\end{array}$ & $\begin{array}{c}\text { Randomized } \\
\text { controlled } \\
\text { trial }\end{array}$ & $\begin{array}{c}30 \\
\text { patients } \\
21 \\
\text { patients }\end{array}$ & $\begin{array}{l}\text { cold knife } \\
\text { VIU } \\
\text { holmium } \\
\text { VIU }\end{array}$ & $\begin{array}{c}\text { Improved } \\
\text { Qmax > } \\
15 \mathrm{ml} / \mathrm{sec}\end{array}$ & $\begin{array}{l}\text { Durability } \\
\text { regarding } \\
\text { restenosis }\end{array}$ & $\begin{array}{l}81 \% \\
53 \%\end{array}$ & $\begin{array}{l}\text { No reported } \\
\text { complication }\end{array}$ & $\begin{array}{l}\text { Heterogenous } \\
\text { etiology and } \\
\text { site of stricture }\end{array}$ \\
\hline $\begin{array}{l}\text { Dutkiewicz } \\
\text { et al. } \\
2011\end{array}$ & $\begin{array}{l}\text { Prospective } \\
\text { clinical trial }\end{array}$ & $\begin{array}{l}50 \\
\text { patients }\end{array}$ & $\begin{array}{l}\text { Cold knife } \\
\text { VIU }\end{array}$ & $\begin{array}{l}\text { Improved } \\
\text { Qmax }\end{array}$ & $\begin{array}{l}\text { Post voiding } \\
\text { residual } \\
\text { Quality of life }\end{array}$ & $\begin{array}{l}\text { The results } \\
\text { obtained did } \\
\text { not confirm } \\
\text { a superiority } \\
\text { based on } \\
\text { Qmax } \\
\text { improvement } \\
\text { and QoL of } \\
\text { one technique } \\
\text { over the other } \\
\text { at 1-year } \\
\text { follow-up. }\end{array}$ & $\begin{array}{c}\text { No reported } \\
\text { complications }\end{array}$ & $\begin{array}{l}\text { No assessment } \\
\text { for success rate } \\
\text { and restenosis } \\
\text { in the study }\end{array}$ \\
\hline
\end{tabular}




\begin{tabular}{|c|c|c|c|c|c|c|c|c|}
\hline $\begin{array}{l}\text { Aboulela } \\
\text { et al. } \\
2018\end{array}$ & $\begin{array}{c}\text { Prospective } \\
\text { clinical } \\
\text { trial for } \\
\text { holmium VIU } \\
\text { compared to } \\
\text { a historical } \\
\text { control of } \\
\text { cold knife } \\
\text { VIU }\end{array}$ & 42 & $\begin{array}{l}\text { Cold knife } \\
\text { VIU }\end{array}$ & $\begin{array}{l}\text { Improved } \\
\text { Qmax at } 3 \\
\text { months > } \\
15 \mathrm{ml} / \mathrm{sec}\end{array}$ & $\begin{array}{c}\text { Post-operative } \\
\text { morbidity }\end{array}$ & $47.6 \%$ & $\begin{array}{c}\text { No reported } \\
\text { complications }\end{array}$ & $\begin{array}{l}\text {-Short follow } \\
\text { up } \\
\text {-Retrospective } \\
\text { analysis } \\
\text {-Non } \\
\text { randomization } \\
\text {-Heterogenous } \\
\text { etiology and } \\
\text { site of stricture }\end{array}$ \\
\hline $\begin{array}{l}\text { Yenice et } \\
\text { al. } \\
2018\end{array}$ & $\begin{array}{c}\text { Randomized } \\
\text { controlled } \\
\text { trial }\end{array}$ & $\begin{array}{c}29 \\
\text { patients } \\
\\
34 \\
\text { patients }\end{array}$ & $\begin{array}{l}\text { Cold knife } \\
\text { VIU } \\
\text { Holmium } \\
\text { VIU }\end{array}$ & $\begin{array}{l}\text { Improved } \\
\text { Qmax }\end{array}$ & $\begin{array}{l}\text { Recurrence rate } \\
\text { Complications }\end{array}$ & $\begin{array}{l}79.3 \% \\
67.3 \%\end{array}$ & $\begin{array}{l}3 \text { cases of urethral } \\
\text { bleeding in cold } \\
\text { knife group } \\
1 \text { case of } \\
\text { extravasation in } \\
\text { holmium group }\end{array}$ & $\begin{array}{l}\text { Small sample } \\
\text { size }\end{array}$ \\
\hline $\begin{array}{l}\text { Karkan et } \\
\text { al. } \\
2019\end{array}$ & $\begin{array}{l}\text { Prospective } \\
\text { single arm } \\
\text { clinical trial }\end{array}$ & 138 & $\begin{array}{l}\text { Holmium } \\
\text { VIU }\end{array}$ & $\begin{array}{l}\text { Improved } \\
\text { Qmax }\end{array}$ & $\begin{array}{c}\text { Recurrence rate } \\
\text { Complications }\end{array}$ & $73.2 \%$ & $\begin{array}{c}24 \text { cases of } \\
\text { intraoperative } \\
\text { hematuria } \\
9 \text { cases of penile } \\
\text { burning sensation }\end{array}$ & $\begin{array}{c}\text { Lack of } \\
\text { comparative } \\
\text { group }\end{array}$ \\
\hline
\end{tabular}

VIU: Visualized internal urethrotomy, Qmax: maximum flow rate

complication rate in our study was $28.8 \%$ representing grades 1,2 and $3 \mathrm{~B}$ with no statistically significant difference. The complications of grades 1 and 2 , including penile edema, bleeding per urethra or UTI, were treated conservatively. The recurrence rate with the need for redo surgery representing grade $3 \mathrm{~B}$ complication was seen in 4 cases in the Holmium group compared to 8 cases in the cold knife group with a statistically significant difference $(P$ value $=0.044)$.

Both surgical techniques of laser and cold knife internal urethrotomy have the advantage to be repeated, but there is no clear evidence for the criteria for the repetition of the procedure (3). We recommend performing a multicentric comparative study between both techniques on a larger sample size with a longer period of follow-up and evaluating their effectiveness in the management of the urethral stricture.

From our study, both the Holmium Laser and cold knife internal urethrotomy are considered safe and effective in the management of a urethral stricture less than 1.5 $\mathrm{cm}$ with a promising outcome after a 1-year follow-up. Holmium laser internal urethrotomy was associated with a longer operative time with a better success rate compared to cold knife urethrotomy.

\section{Ethical considerations}

The study was approved by the Research Ethics Committee of Faculty of Medicine, Ain Shams University (FWA000017585), with ID: R55/2017. The study was conducted in accordance with the declaration of Helsinki. The study was registered on Clinicaltrial.gov with ID number: NCT04650347.

\section{Consent for Participation}

written consent was obtained from all patients before participation.

\section{Conflict of Interests}

Nothing to declare.

\section{Funding}

No fund was received for our study.

\section{References}

1. Torres Castellanos L, Moreno Bencardino MC, BravoBalado A, García Mayorga CA, Vargas Manrique I, Fernández N. Evaluation of the Efficacy and Safety of Laser versus Cold Knife Urethrotomy in the Management of Patients with Urethral Strictures: A Systematic Review and Meta-Analysis of Randomized Clinical Trials. Urol Int .2017;99(4):453-9. doi: 10.1159/000478026

2. Zhou S, Zhang J, Sa Y, Jin S, Xu Y, Fu Q, et al. Etiology and Management of Male Iatrogenic Urethral Stricture: Retrospective Analysis of 172 Cases in a Single Medical Center. Urol Int.2016;97(4):386-91. doi: 10.1159/000444592

3. Aboulela W, ElSheemy MS, Shoukry M, Shouman AM, Shoukry AI, Ghoneima W, et al. Visual internal urethrotomy for management of urethral strictures in boys: a comparison of short-term outcome of holmium laser versus cold knife. Int Urol Nephrol. 2018 Apr 3;50(4):605-9. doi: 10.1007/s11255-018-1809-x

4. Mundy AR, Andrich DE. Urethral strictures. BJU Int. 2011 Jan;107(1):6-26. doi: 10.1111/j.1464-410X.2010.09800.x

5. Higazy A, Tawfeek AM, Abdalla HM, Shorbagy A, Mousa W, Radwan AI. Holmium laser enucleation of the prostate versus bipolar transurethral enucleation of the prostate in management of benign prostatic hyperplasia: A randomized controlled trial. Int J Urol. 2020 Dec 16;iju.14462. doi: 10.1111/iju. 14462

6. Peterson AC, Webster GD. Management of urethral stricture disease: developing options for surgical intervention. BJU Int. 2004 Nov;94(7):971-6. doi: 10.1111/j.1464410X.2004.05088.x

7. Singh B, Jain S, Kaza RC. Evaluation of holmium laser 
versus cold knife in optical internal urethrotomy for the management of short segment urethral stricture. Urol Ann. 2014;6(4):328. doi: 10.4103/0974-7796.140997

8. Herrmann TRW, Liatsikos EN, Nagele U, Traxer O, Merseburger AS. EAU Guidelines on Laser Technologies. Eur Urol. 2012 Apr;61(4):783-95. doi: 10.1016/j. eururo.2012.01.010

9. Razzaghi MR, Karkan MF, Ghiasy S, Javanmard B. Laser application in Iran urology: A narrative review. J Lasers Med Sci. 2018;9(1):1-6. doi: 10.15171/jlms.2018.01

10. Futao S, Wentong Z, Yan Z, Qingyu D, Aiwu L. Application of endoscopic Ho:YAG laser incision technique treating urethral strictures and urethral atresias in pediatric patients. Pediatr Surg Int. 2006 Jun 29;22(6):514-8. doi: 10.1007/s00383-006-1692-x

11. Dutkiewicz SA, Wroblewski M. Comparison of treatment results between holmium laser endourethrotomy and optical internal urethrotomy for urethral stricture. Int Urol Nephrol . 2012 Jun 30;44(3):717-24. doi: 10.1007/s11255011-0094-8

12. Sachse S. Meta analysis Safety and efficacy of laser and cold knife urethrotomy for. 2010;123(12):1589-95. doi: 10.3760/ cma.j.issn.0366-6999.2010.12.020

13. Barbagli G, De Stefani S, Sighinolfi MC, Pollastri CA, Annino F, Micali S, et al. Experience with fibrin glue in bulbar urethral reconstruction using dorsal buccal mucosa graft. Urology. 2006 Apr;67(4):830-2.

14. Andrich DE, Mundy AR. Urethral strictures and their surgical treatment. BJU Int [Internet]. $2001 \mathrm{Dec}$
24;86(5):571-80. doi: 10.1046/j.1464-410x.2000.00878.x

15. MacDonald MF, Santucci RA. Review and treatment algorithm of open surgical techniques for management of urethral strictures. Urology. 2005 Jan;65(1):9-15. doi: 10.1016/j.urology.2004.07.011

16. Lagerveld BW, Laguna MP, Debruyne FMJ, De La Rosette JJMCH. Holmium:YAG Laser for Treatment of Strictures of Vesicourethral Anastomosis after Radical Prostatectomy. J Endourol. 2005 May;19(4):497-501. doi: 10.1016/j. urology.2004.07.011

17. Dogra PN, Nabi G. Neodymium-YAG Laser Core through Urethrotomy in Obliterative Posttraumatic Urethral Strictures after Failed Initial Urethroplasty. Urol Int. 2002;68(4):265-7. doi: 10.1159/000058448

18. Yenice MG, Seker KG, Sam E, Colakoglu Y, Atar FA, Sahin S, et al. Comparison of cold-knife optical internal urethrotomy and holmium:yag laser internal urethrotomy in bulbar urethral strictures. Cent Eur J Urol. 2018;71:11420. doi: 10.5173/ceju.2017.1391

19. Atak M, Tokgöz H, Akduman B, Erol B, Dönmez İ, Hancı $\mathrm{V}$, et al. Low-power holmium:YAG laser urethrotomy for urethral stricture disease: Comparison of outcomes with the cold-knife technique. Kaohsiung J Med Sci. 2011 Nov;27(11):503-7. doi: 10.10a16/j.kjms.2011.06.013

20. Karkan MF, Razzaghi MR, Karami H, Ghiasy S, Tayyebiazar A, Javanmard B. Experience of 138 transurethral urethrotomy with holmium: YAG laser. J Lasers Med Sci. 2019;10(2):104-7. doi: 10.15171/jlms.2019.17 